\title{
Seroprevalence of HTLV I-II, HIV and HCV Antibodies in Lymphoma, Head and Neck Cancer Patients
}

\author{
Nuray BUYUKBERBER ${ }^{1}$, Tulay YALCINKAYA ${ }^{2}$, Ramazan YILDIZ ${ }^{3}$, Ugur COSKUN ${ }^{3}$, \\ Mustafa BENEKLI ${ }^{3}$
}

${ }^{1}$ Gazi University Faculty of Medicine, Department of Medical Microbiology, Ankara
${ }^{2}$ Turkish National Institute of Health, Microbiology Reference Laboratory, Ankara

${ }^{3}$ Gazi University Faculty of Medicine, Department of Medical Oncology, Ankara, TURKEY

\begin{abstract}
Human T-cell lymphotropic virus type I (HTLV I), which has a worldwide distribution, is the first human retrovirus mainly to be associated with malignant diseases, such as adult T-cell leukemia-lymphoma and bronchioloalveolar carcinoma. Tip II (HTLV II), a retrovirus having genomic homology with the HTLV I, has not been proven to be a pathogenic virus so far. Hepatitis C virus (HCV), an RNA virus, is the cause of acute and chronic hepatitis, cirrhosis and liver cancer. Human immunodeficiency virus (HIV syn. HTLV III), is a factor in AIDS. Studies on the development of malignant diseases of these viruses are restricted in all over the world, there is no detailed study was found in our country as well. In this study, the seropositivity of HTLV I-II, HIV and HCV viruses in lymphoma and head and neck cancer patients and the relationship between these viruses and these cancers evaluated. As a result HTLV I-II seropositivity was found in 2 of 86 lymphoma and 2 of 80 head and neck cancer patients. There is a need for further large studies related to those and other viral agents caused malignancies.
\end{abstract}

Keywords: HTLV, HIV, HCV, Lymphoma, Head and neck carcinoma

\section{ÖZET}

\section{Lenfoma ve Baş-boyun Kanserli Hastalarda HTLV I-II, HIV ve Anti-HCV Seropozitifliğinin Değerlendirilmesi}

Insan T-hücre lenfotropik virüs Tip I (HTLV-I), çoğunlukla adult T hücreli lösemi-lenfoma olmak üzere bronşioalveolar karsinoma gibi malign hastalıklarla ilişkisi ispatlanmış, dünyada yaygın, ilk insan retrovirüsüdür. Tip II (HTLV-II) patojen olduğu tam olarak kanıtlanmamakla birlikte HTLV-I ile genomik olarak homolojisi olan bir retrovirüstür. Hepatit C virüsü (HCV) akut-kronik hepatit, siroz ve karaciğer kanserinin majör sebebi olan RNA virüsüdür. İnsan immün yetmezlik virüsü (HIV syn. HTLV-III), AIDS hastalı̆ının etken virüsüdür. Bu virüslerin malign hastalıkların olușumu ve gelişimi ile ilgili çalıșmalar tüm dünyada kısıtı olup ülkemizde ise ayrıntılı bir çallşmaya rastlanmamıştır. Bu çalışmada lenfoma ve baş-boyun karsinomu tanısı almış hastalarda HTLV I-II, HIV ve HCV virüslerinin varlığını ve bu virüslerin bu kanserlerle ilişkisi değerlendirildi. Sonuç olarak 86 lenfoma hastasının ikisinde ve 80 baş-boyun kanserli hastanın da ikisinde HTLV I-II seropozitifliği tespit edildi. Bu ve diğer viral etkenlerin sebep olduğu malignitelerde yapılacak daha büyük çalışmalara intiyaç vardır.

Anahtar Kelimeler: HTLV, HIV, HCV, Lenfoma, Baş-boyun karsinomu 


\section{INTRODUCTION}

Human T-lymphotropic virus types I and II (HTLV I and II); are two closely related retroviruses belonging to the genus Deltaretrovirus present in Retrovirus family. HTLV II has a similar genome structure and shares approximately $70 \%$ nucleotide sequence homology with HTLV I. ${ }^{1}$ Although the number of HTLV I seropositive individuals is not known exactly, it is estimated that $15-20$ millions individuals have HTLV infection worldwide. ${ }^{2}$ HTLV I has been substantially linked to human diseases such as adult T-cell leukemia/lymphoma (ATL), myelopathy/tropical spastic paraparesis (HAM/TSP) and uveitis (HAU). ${ }^{3}$ The geographic distribution of the virus has been studied since its initial description, with Japan, where HTLV I is endemic, Africa, the Caribbean islands, Central and South America emerging as the areas of the highest prevalence in all over the world High rates of HTLV I infection have been reported for some Caribbean islands in studies of healthy blood donors in the general population. Moreover, HTLV I infection might cause subclinical immune suppression that can result in an elevated rate of opportunistic coinfections such as tuberculosis and strongyloidiasis. ${ }^{4}$ Preceding research also have described that arthritis, urinary tract disorders, fibromyalgia, and major depression were often found in HTLV I infected populations. ${ }^{5-8}$

Chronic Hepatitis C virus (HCV) infection is a universal problem, affecting more than 170 million persons worldwide. ${ }^{9}$ Individuals with chronic HCV infection have an amplified risk of developing cirrhosis and hepatocellular carcinoma. ${ }^{10,11}$ Furthermore, HCV has been associated with other nonhepatic cancer types such as multiple myeloma (MM) and thyroid cancer (TC). ${ }^{12}$ Since HCV is a blood-borne virus, $\mathrm{HCV}$-infected persons have been at risk of catching other unknown blood-borne infections that might lead to the development of malignant tumors. Additionally, Chronic HCV confers an increased risk of non-Hodgkin lymphoma (NHL) and other hematopoietic malignancies ${ }^{13}$, presumably through lymphoproliferative mechanisms. ${ }^{14}$

Human immunodeficiency virus (HIV) infection is a well-recognized risk factor for malignant lymphoma, which is more common among individuals with a severe immune deficiency and is considered an AIDS-defining event. The incidence of NHL among HIV-infected patients has decreased significantly since the introduction of highly active antiretroviral therapy in $1996 .{ }^{15}$

Historically, the occurrence of only three types of cancer in a person infected with HIV, namely Kaposi's sarcoma, NHL, and cervical cancer, has constituted an AIDS diagnosis. ${ }^{16}$ However, in populationbased cohort studies has seen that a few other cancers including Hodgkin's lymphoma (HL), lip cancer, brain cancer and possibly testicular seminoma seem to occur at increased rates in people with HIV/AIDS. ${ }^{17-19}$

The substantial improvement in survival after HIV infection has led to increasing public health and clinical interest in long-term morbidities, including cancer, patients with HIV in some countries. ${ }^{20,21}$ Therefore it is important to determine HIV seroprevalence in Turkish cancer patients mostly lymphoma for possible treatment and augmentation of health. Moreover, a study in Danish population demonstrated that HIV appears to be a marker of behavioral or family-related risk factors that affect the incidence of head and neck cancers in HIV serapositive patients ${ }^{22}$ thus the search for HIV in head and neck cancer patients will give information about HIV incidence in these types of cancer patients in our country.

\section{MATERIALS and METHODS}

Serum specimens of 166 cancer patients, 86 diagnosed with lymphoma (44 male, 42 female) with a median age of 58 (range, 23-84) years, 80 diagnosed with head and neck cancer (59 male, 21 female) with a median age of 57 (range, 27-84) years in Gazi University Medical Faculty Hospital, were examined for the presence of HTLV I-II, HIV and $\mathrm{HCV}$ antibodies (Table 1). Serum samples were obtained, centrifuged and stored at $-80^{\circ} \mathrm{C}$ until tested. They were then screened for anti- HTLV-I-II antibodies with an EI A(Enzyme immune assay) (DIA. PRO Sesto San Giovanni, Milano-ITALY); HIV-I and II antibodies with an EIA (DIA. PRO Sesto San Giovanni, Milano-ITALY) and HCV antibodies were also performed HCV antibodies with an EIA (DIA.PRO Milano-ITALY). Each serum sample was examined following the manufacturer's instructions. Serum samples that were positive for an- 


\begin{tabular}{|c|c|c|c|c|}
\hline & \multicolumn{2}{|c|}{ Lymphoma } & \multicolumn{2}{|c|}{ Head and Neck } \\
\hline & $\mathrm{n}=86$ & (\%) & $\mathrm{n}=80$ & $(\%)$ \\
\hline Median age in years (range) & \multicolumn{2}{|c|}{$58(23-84)$} & \multicolumn{2}{|c|}{$57(27-84)$} \\
\hline \multicolumn{5}{|l|}{ Sex } \\
\hline Female & 42 & 48.8 & 21 & 26.3 \\
\hline Male & 44 & 51.2 & 59 & 73.7 \\
\hline \multicolumn{5}{|l|}{ Lymphoma type } \\
\hline $\mathrm{NHL}$ & 73 & 84.9 & & \\
\hline $\mathrm{HL}$ & 13 & 15.1 & & \\
\hline \multicolumn{5}{|c|}{ Primary tumor site for head and neck carcinoma } \\
\hline Larynx & 38 & 47.5 & & \\
\hline Nasopharynx & 12 & 15.0 & & \\
\hline Oral cavity & 22 & 27.5 & & \\
\hline Other sites & 8 & 10.0 & & \\
\hline \multicolumn{5}{|l|}{ Chemotherapy } \\
\hline $\mathrm{CHOP} \pm \mathrm{R}$ & 64 & 74.4 & & \\
\hline ABVD & 13 & 15.1 & & \\
\hline \multicolumn{2}{|l|}{ Platin-based chemotherapy } & & 72 & 90 \\
\hline Radiotherapy & 28 & 32.6 & 68 & 85 \\
\hline
\end{tabular}

tibodies against HTLV I-II, HCV and HIV by the EIA were then scored as low, intermediate, or high according to the measurement of the color intensity of the solution in each well.

\section{RESULTS}

Lymphoma patients in the study population primarily had diagnosis of NHL (84.9\%), with most common subtype of diffuse large B cell lymphoma, and HL $(15.1 \%)$. Primary chemotherapy regimens were cyclophosphamide, doxorubicin, vincristine, prednisolone, rituximab $(\mathrm{CHOP} \pm \mathrm{R})(74.4 \%)$ in $\mathrm{NHL}$ and doxorubicin, bleomycin, vinblastine, dacarbazine (ABVD) (15.1\%) in HL patients. Primary tumor site for head and neck cancers were larynx $(47.5 \%)$, nasopharynx (15\%) and oral cavity $(27.5 \%)$. Platin-based chemotherapy regimens most commonly used for these cancers and $85 \%$ of patients had radiotherapy concomitantly (Table 1 ). Serum samples from these head and neck carcino- ma and lymphoma patients were examined for HTLV I-II, HCV and HIV seroprevalence. In totally 86 lymphoma patients, only two from 44 male lymphoma patients, total of $2.32 \%$, were seropositive for HTLV I-II, whereas no seropositivity was found in female patients' serum samples for the same virus (Table 2). There was no seropositivity observed for HCV and HIV antibodies in patients had lymphoma in both sex. In totally 80 head and neck cancer patients, only one male out of 59 and only one female out of 21 , total of $2.5 \%$ patients were seropositive for HTLV I-II. When the same serum specimens were analyzed for HCV and HIV antibodies, there was no seropositivity in head and neck cancers. According to our results, there was no significant relation between virus seroprevalence and sex in both lymphoma and head and cancer. Among all patients' serum samples in both cancer type only HTLV I-II antibodies was present comparison to the other virus types in this study. 


\begin{tabular}{|c|c|c|c|c|}
\hline \multirow[b]{2}{*}{ Sex } & \multicolumn{2}{|c|}{ Lymphoma } & \multicolumn{2}{|c|}{ Head and Neck Cancer } \\
\hline & Male & Female & Male & Female \\
\hline \multicolumn{5}{|l|}{ Virus } \\
\hline $\mathrm{HCV}$ & - & - & - & - \\
\hline HIV & - & - & - & - \\
\hline HTLV I -II & 2 & - & 1 & 1 \\
\hline
\end{tabular}

\section{DISCUSSION}

Incidence of several malignancies was reported in a nationwide cohort studies related to $\mathrm{HCV}$-infected individuals. Although the delayed diagnosis of HCV probably has resulted in an underestimation of the risk, a study showed a significantly increased risk of NHL and MM in those infected patients. ${ }^{23}$

$\mathrm{HCV}$ has been suggested to be both hepatotropic and nonhepatic in other words lymphotropic. ${ }^{24,25}$ Furthermore, the HCV has nonhepatic oncogenic potential since chronic HCV confers an increased risk of NHL and other hematopoietic malignancies and thyroid cancer. A Swedish group studied the incidence of Chronic lymphocytic leukemia (CLL), Acute lymphocytic leukemia (ALL), NHL, HL, $\mathrm{MM}$, and TC in the entire cohort of notified $\mathrm{HCV}$ patients in Sweden. The results showed an increased risk for Swedish patients with HCV to develop B-cell NHL and MM. ${ }^{23}$

However, the role of $\mathrm{HCV}$ in the pathogenesis of other lymphoproliferative disorders is controversial. In some studies, the prevalence of HCV infection has significantly increased among patients with B-cell NHL, which is the case in studies performed in Italy, also in Japan and the United States..$^{26-30}$ Yet, this association has not been demonstrated in studies from Northern Europe, and additionally regional differences have been suggested..$^{31,32}$ According to the findings of this study in patients with lymphoma and carcinoma of the head and neck, no seropositivity was observed for HCV in 166 cancer patients. That correlates with the study conducted in Northern Europe.
Former research reported that several infectious agents including HIV as well as acquired immune deficiency are among the risk factors of NHL. Results of this study in patients with lymphoma and carcinoma of the head and neck, no seropositivity was observed for HIV. A recent meta-analysis was conducted in an increased risk of cancer in both HIV/AIDS and immunosuppressed patients after organ transplant. The researchers suggested immune deficiency, rather than other risk factors, is responsible for the increased risk for cancer. ${ }^{20}$ Therefore it can be said that HIV is not the direct reason for the cancer development, which supported by our findings.

Our experimental study resulted only seropositivity for HTLV I and II in both tumor groups. A respected study took place in Turkey on 913 healthy blood donors, completed in İzmir, serum specimens were seronegative for HTLV I-II and HIV, on the other hand samples were reactive for HCV antibodies $(0.3 \%))^{33}$ In a further study applied by the same investigators, serum samples from 10.000 healthy blood donors were screened for HTLV-I/II antibodies by a commercial enzyme immunoassay method..$^{34}$ Consequently, samples yielded reactive/borderline reactive results by both ELISA lots, however, all of them were found negative by confirmatory test. Same researchers also mentioned that 43 NHL and 15 CLL patients were screened for HTLV-I/II antibodies, and consequently seropositivity was not determined. Therefore the investigators concluded that those viruses were not endemic in that geographical region. In accordance with the preceding study, our findings also indicated that HTLV I-II, HCV and HIV are not common in selected cancer patients. Despite the previous study was conducted in healthy general population, and a small group of cancer patients, our study included only cancer patients.

A total of 166 men and women were evaluated in this comprehensive study of cancer patient sera, as a result, the role of these viruses in the development of these tumors remains to be still indistinct. Extensive studies, will take place in our country, including more and different type of cancer patients on these viruses, which better illuminate their role in the development of these types of cancers. 
Conflict of interest: No author of this paper has a conflict of interest, including specific financial interests, relationships, and/or affiliations relevant to the subject matter or materials included in this manuscript.

\section{REFERENCES}

1. Manns A, Blattner WA. The epidemiology of the human T-cell lymphotrophic virus type I and type II: etiologic role in human disease. Transfusion 1: 67-75, 1991.

2. de The G, Kazanji M. (1996). J. Acq. Immun. Def. Synd. Hum. Retrovirol 13 (Suppl 1): S191-S198, 1996.

3. Proietti FA, Carneiro-Proietti AB, Catalan-Soares BC, Murphy EL. Global epidemiology of HTLV-1 infection and associated diseases. Oncogene 24: 6058-6068, 2005.

4. Bangham $\mathrm{CR}$, Osame M. Cellular immune response to HTLV-1. Oncogene 24: 6035-6046, 2005.

5. Cruz BA, Catalan-Soares B, Proietti F. Higher prevalence of fibromyalgia in patients infected with human $T$ cell lymphotropic virus type I. J Rheumatol 33: 23002303, 2006.

6. Mori K, Noguchi M, Matsuo M, et al. Natural course of voiding function in patients with human T-cell lymphotrophic virus type 1-associated myelopathy. J Neurol Sci 217: 3-6, 2004.

7. Oliveira P, Castro NM, Carvalho EM. Urinary and sexual manifestations of patients infected by HTLV-I. Clinics 62: 191-196, 2007.

8. Stumpf BP, Carneiro-Proietti AB, Proietti FA, Rocha FL. The Interdisciplinary HTLV Research Group. Higher rate of Rocha major depression among blood donor candidates infected with human T-cell lymphotropic virus type 1. Int. J. Psychiatry Med 38: 345-355, 2008.

9. WHO. Hepatitis C: global prevalence. Wkly Epidemiol Rec 72: 341-344, 1997

10. Tong MJ, el-Farra NS, Reikes AR, Co RL. Clinical outcomes after transfusion-associated hepatitis C. N Engl J Med 332: 1463-1466, 1995.

11. Poynard T, Bedossa P, Opolon P. Natural history of liver fibrosis progression in patients with chronic hepatitis C. The OBSVIRC, METAVIR, CLINIVIR, and DOSVIRC groups. Lancet 349: 825-832, 1997.

12. Montella M, Crispo A, de Bellis G, et al. HCV and cancer: a case-control study in a high-endemic area. Liver 21: 335-341, 2001.

13. Giordano TP, Henderson L, Landgren O, et al. Risk of non-Hodgkin lymphoma and lymphoproliferative precursor diseases in US veterans with hepatitis $\mathrm{C}$ virus. JAMA 297: 2010-2017, 2007.
14. Pal S, Sullivan DG, Kim S, et al. Productive replication of hepatitis $C$ virus in perihepatic lymph nodes in vivo: implications of HCV lymphotropism. Gastroenterology 130: 1107-1116, 2006.

15. Kirk O, Pedersen C, Cozzi-Lepri A, et al. Non-Hodgkin lymphoma in HIV-infected patients in the era of highly active antiretroviral therapy. Blood 98: 3406-3412, 2001.

16. Centers for Disease Control. Revision of the CDC Surveillance Case Definition for acquired immunodeficiency syndrome. JAMA 258: 1143-1149, 1987.

17. Biggar RJ, Jaffe ES, Goedert JJ, et al. Hodgkin lymphoma and immunodefi ciency in persons with HIV/AIDS. Blood 108: 3786-3791, 2006.

18. Grulich AE, Li Y, McDonald A, et al. Rates of nonAIDS-defining cancers in people with HIV infection before and after AIDS diagnosis. AIDS 16: 1155-1161, 2002.

19. Frisch M, Biggar RJ, Goedert JJ. Humanpapillomavirus-associated cancers in patients with human immunodefi ciency virus infection and acquired immunodeficiency syndrome. J Natl Cancer Inst 92: 1500-1510, 2000.

20. Grulich AE, van Leeuwen MT, Falster MO, Vajdic CM. Incidence of cancers in people with HIV/AIDS compared with immunosuppressed transplant recipients: a meta-analysis. The Lancet 370: 94-101, 2007.

21. Engels EA, Biggar RJ, Hall HI, et al. Cancer risk in people infected with human immunodeficiency virus in the United States International Journal of Cancer 123: 187-194, 2008.

22. Engsig FN, Gerstoft J, Kronborg G, et al. Head and neck cancer in HIV patients and their parents: A Danish cohort study. Clinical Epidemiology 3: 217-227, 2011.

23. Duberg Ann-Sofi, Nordström M, Törner A, et al. NonHodgkin's Lymphoma and Other Nonhepatic Malignancies in Swedish Patients with Hepatitis C Virus Infection Hepatology 41: 652-659, 2005.

24. Ferri C, La Civita L, Zignego AL, Pasero G. Viruses and cancers: possible role of hepatitis C virus. Eur J Clin Invest 27: 711-718, 1997.

25. Weng WK, Levy S. Hepatitis C virus (HCV) and lymphomagenesis. Leuk Lymphoma 44: 1113-1120, 2003.

26. Ferri C, Caracciolo F, Zignego AL, et al. Hepatitis C virus infection in patients with non-Hodgkin's lymphoma. Br J Haematol 88: 392-394, 1994.

27. De Rosa G, Gobbo ML, De Renzo A, et al. High prevalence of hepatitis $C$ virus infection in patients with B-cell lymphoproliferative disorders in Italy. Am J Hematol 55: 77-82, 1997.

28. Montella M, Crispo A, de Bellis G, et al. HCV and cancer: a case-control study in a high-endemic area. Liver 21: 335-341, 2001.

29. Mizorogi F, Hiramoto J, Nozato A, et al. Hepatitis C virus infection in patients with B-cell non-Hodgkin's lymphoma. Intern Med 39: 112-117, 2000. 
30. Zuckerman E, Zuckerman T, Levine AM, et al. Hepatitis $C$ virus infection in patients with B-cell non-Hodgkin lymphoma. Ann Intern Med 127: 423-428, 1997.

31. McColl MD, Singer IO, Tait RC, et al. The role of hepatitis $C$ virus in the aetiology of non-Hodgkins lymphoma - a regional association? Leuk Lymphoma 26: 127-130, 1997.

32. Hausfater $P$, Cacoub P, Sterkers $Y$, et al. Hepatitis C virus infection and lymphoproliferative diseases: prospective study on 1,576 patients in France. Am $J$ Hematol 67: 168-171, 2001.

33. Sertöz RY, Erensoy S, Özçam H, et al. Anti-HTLV-I/II Seroprevalence in Healthy Blood Donors in Izmir, Turkey. Turk J Hematol 20: 81-83, 2003.

34. Sertöz R, Turhan A, Bozkurt H, et al. Investigation of anti-HTLV I/II seroprevalence in healthy blood donors in Izmir region, Turkey. Mikrobiyol Bul 44: 579-584, 2010.

\section{Correspondence:}

Dr. Nuray BÜYÜKBERBER

Gazi Üniversitesi Tıp Fakültesi

Mikrobiyoloji Anabilim Dalı

Beşevler, ANKARA / TURKEY

Tel: (+90.312) 2025830

Fax: (+90.312) 2158710

e-mail: nbuyukberber@gazi.edu.tr 